\title{
A Single Input Dual Output Multiport DC-DC Converter with Minimal Switches
}

\author{
P.Priyanka, S.Muthubalaji
}

\begin{abstract}
This paper proposes a topology for multiport $D C$ DC converter with double yield for a solitary facts. Essentially the buck converter's yield is lesser than the records. Boost converter's yield is more distinguished than the info. buck-boost converter's yield is each more noteworthy or lesser than the facts. Be that as it is able to, the interest of the proposed converter is, it surrenders the both increase and undertaking down yields all the at the same time as. The contemporary-day topology of the multiport DC-DC Converter applied four switches however the proposed topology uses less number of switches with excessive yield contrasted with existing one. It likewise brings approximately decrease of replacing misfortunes. The skillability of the converter is improved, yield voltages get controlled and the charge of the circuit diminishes because of its minimization. The near circle PI controlling approach is embraced. The results were checked with the resource of making use of MATLAB simulink software program program
\end{abstract}

Key terms:- single enter, dual Output, Dc-Dc Converter, dollar and enhance.

\section{INTRODUCTION}

Because the populace is increasing step by step little by little turns on the growth in the hobby of electrical energy. electricity is the fundamental requirement for the improvement of a country. the electrical strength is created at the a ways flung areas and transmitted to dispersion focuses via transmission traces. right here the electricity virtual converters count on an crucial process. The essential static strength converters are rectifiers, inverters, choppers, aircon voltage controllers and cycloconverters.because the normal power assets are tends to draining, the optionally available techniques are picked to create electric power handiest sustainable energy assets typically from the solar, wind, tides, seas, geothermal, biomass and plenty of others.in the sustainable strength sources manipulate age plants and in electric powered powered pressure unit, vitality exchange continuously includes a DC section. So it's miles obligatory to pay attention on the dc-dc converters.DC-DC converters changes over constant direct voltage to variable/controllable direct voltage. those are of 3 kinds to be particular dollar, deliver and dollar-help converter. For an information voltage buck converter gives lesser yield voltage, guide converter gives higher yield voltage and greenback-assist converter offers both lesser or better yield voltages than the data voltage.

As a super development takes place within the power devices place, multiport converters are in all likelihood the quality good buy. It regards the entire framework as a solitary electricity converter, gives high effectiveness. Multiport dc-dc converters are conservative in shape with an awful lot less segments, lower value contrasted with diverse DC-DC converters.

AlessioClerici, et.al [1] talked about that the big patron of strength is open transportation frameworks. The relevant growing of teach energy request and the over-burden of a few railroad traces is making growing enthusiasm about strength monetary savings.Reinjecting electric electricity from the slowing mechanism into the air conditioner system is probably difficult. So current air con/dc substations seem like the most becoming spot to introduce additional hardware. Multiport converters are provided due to the fact the maximum in fact realistic answer for this execution.

Hongfeiwu, et.al [2] encouraged that energy stockpiling framework is a essential element in a single-of-a-kind power frameworks. Bidirectional AC-DC converter is a key device to interface the $\mathrm{AC}$ matrix and a potential issue. effective and adaptable power exchange amongst $\mathrm{AC}$ network and ability additives is a noteworthy test. energy trade the various battery and the community may be finished uniquely through the 3-port converter inner single strength change installation.

AmitBhattacharjee, et.al [3] recommended that a thorough survey of multiport converter topologies for incorporating PV with energy stockpiling. The principle motivation in the back of the MPC is to give a solitary degree manipulate trade that essentially coordinates various energy belongings at the same time as protective their extraordinary attributes, for instance, MPPT for PV frameworks and charging/liberating potential for batteries.

Amir Ganjavi, et.al [4] recommended that a singular non segregated single-input double yield 3 -stage dc-dc converter right for medium and immoderate-voltage applications. it's far an incorporation of the 3-stage dollar and lift converters, whose yield voltages are managed all the at the same time as. This exam deliberate for structuring a excessiveproficiency multiport dc-dc converter with diminished voltage fear crosswise over semiconductor devices and shrunk indifferent components duration.

H.Kung,Gregory J. Kish [5] encouraged that DC transmission has one-of-a-kind blessings over AC transmission for mass vitality skip over long gets rid of, inclusive of higher productivity and decrease transmission

Revised Manuscript Received on August 19, 2019.

P.Priyanka,PG Scholar, Department of EEE CMR College of Engineering \&Technology, Kandlakoya, Hyderabad, Telangana. India (priyaparankusham@gmail.com)

S.Muthubalaji, Professor, Department of EEE, CMR College of Engineering \&Technology, Kandlakoya, Hyderabad, Telangana. India (muthusa15@gmail.com) 
line fee. Multiport HV DC-DC converters are required to encourage future HVDC basis with the capability to interconnect and oversee strength circulate amongst awesome HVDC structures. so that multiport precise staggered converter is utilized.

Mohammad Sameer Irfan, et.al [6] suggested that a summed up electricity-decoupling manipulate plan making use of a multiport secluded bidirectional converter for a staggered inverter, which has numerous dc interfaces inside. in this a solitary power-decoupling capacitor is wanted for all the dc connects within the staggered inverter. film capacitors are finished in place of the electrolytic ones, to improve the lifetime and unwavering superb.

Mohammed Alsolami, et.al [7] advocated that united statesframeworks are meant to present best, tailored, and uninterruptible ability to number one hardware, for example, computers, restorative gear, stockpiling frameworks, and one-of-a-kind cutting-edge hardware. This paper proposed a singular topology of a measured UPS, in mild of exchanged capacitor circuit and wideband hollow devices. The crucial willpower is the locating that allows superb burden safety joined with an incredibly gifted interest in normal mode and consistent change capacity to the reinforcement mode.

BaburajKaranayil, et.al [8] counseled that the legitimization of intensity belongings has brought on an electrical air ship structure in which conventional devices are supplanted with the useful resource of electrical frameworks. on this a energy go with the flow the board framework for little by little electric powered powered air deliver by way of using incorporating a disconnected multiport bidirectional electricity converter with three HVDC transports are applied. one in every of the trendy agency shipping flying gadget Boeing 787 is carried out in this mission.

Chun Gan, et.al [9] this paper tended to a multiport bidirectional exchanged hesitance engine pressure for daylight based totally definitely helped cross breed electric powered shipping energy teach, improves the motoring execution and accomplishes adaptable charging capacities. miles and self-charging capability.

MatteoCorti, et.al [10] recommended that DC organizes that consist of stockpiling frameworks, inexhaustible assets, dc loads, and the front-quit converters can supply a few focal factors as compared with air con network. Be that as it may, the intrusion of deficiency flows is difficult because of incapability clearing time of commonplace DC circuit breakers may be unreasonably long for securing electricity digital changing segments. Multiport converters look like a first rate solution for searching after the formerly stated hassle.

Fan Yi, Wen Cai [11] exhibited a semi Z-supply included multiport converter for exchanged hesitance engine drives to lessen the dc-interface capacitance and empower large-pace skip pastime. With switch multiplexing device, it's miles decided to carry out strength swell lower making use of normally little capacitor.

Fan Yi, Wen Cai [12] proposed a summed up control approach for battery-pushed exchanged hesitance engine drives dependent on coordinated multiport manipulate Photovoltaic boards are added at the transport for visiting no-zero intersection of the current. in addition, the

converter. big power swell brought approximately through the triumphing opportunity is a take a look at hassle for SRM drives.

Wen Cai, Fan Yi [13] offers the conventional pressure for the exchanged hesitance engine is predicated upon on a deviated H-connect which dreams sizeable capacitor on the dc shipping to preserve the quick strength delivered approximately by modern substitution. The proposed topology contains of a multiport converter which offers the dc delivery capacitor as an additional port however the data port and is coordinated depending on the switch multiplexing gadget.

MihaescuMihai [14] encouraged that over the previous years inside the strength devices situation, due to the advances enrolled on this area, an improvement of multiport converters topologies can be expressed. the ones converters have severa statistics and yield ports to which certainly one of a type energy elements and masses can interface. The multiport systems increase the chance of making the whole framework increasingly basic and minimized.

ErdemAsa, et.al [15] in this paper, a singular multiport CLL entire converter with a diploma flow into and unbalanced responsibility cycle manipulate is broke down. The strength flow into can be stored up with the extent waft among ports, while the lopsided obligation cycle offers with the yield voltage at the heap terminals. affiliation related transformers on the auxiliary facet empower to element the power in every port and reduce the voltage weights on the switches contrasted and the parallel associated transformers.

Kenichi Itoh, et.al [16] broke down and deliberate a unique multiport $\mathrm{dc}-\mathrm{dc}$ converter with a coupling appealing inductor. The proposed circuit coordinates multiphase converters and one disconnected $\mathrm{dc}-\mathrm{dc}$ converter. these converters may be managed autonomously in one circuit with the useful resource of changing the duty percentage and level facet comparison. There are four dc ports within the circuit, and the dc strength may be conveyed multidirectional a number of the 4 dc ports.

Hongfei $\mathrm{Wu}$, et.al [17], a planned approach for determination of a multiport converter depending on the dcjoin inductor concept is proposed in this paper. The MPC is created via interconnecting severa throbbing voltage cells via the DC be a part of inductors. The throbbing voltage cells may be facts type, yield kind, and bidirectional type. The bidirectional multiport converter topologies may be reaped if all of the throbbing voltage cells are bidirectional kind. With the proposed multiport converters, step-up and step-down voltage alternate between the 2 ports can be done.

Joshua T. Hawke, et.al [18] advocated that for softwarescale energy unit control age, multiport manipulate sharing converter topologies are useful. severa power module assets are related to a medium voltage network via a solitary staggered NPC inverter with excessive-recurrence segregation.

Venmathi M. what is more, Ramaprabha R. [19] recommended that a immoderate recurrence aircon

Published By: 
connection based totally converter is called as a multi-port converter in which ports are related to the energy assets, strength stockpiling devices and the heap. Bidirectional power move among the heap port and the electricity stockpiling devices are done so you can maintain up the strength balance inside the framework.

As from the writing a big part of the topologies carried out numerous switches which result in the boom in changing misfortunes and the topologies are likewise complex.moreover,these converters are applied to power the machines like exchanged hesitance engines for diverse applications. The utilization of massive wide sort of modifications turns on the warming and bring the converting stresses. those may also purpose the breaking down of drives and effect its presentation.

via thinking about all the previously noted problems, this paper proposes a multiport converter with decreased wide kind of switches(handiest two switches) with out bargaining the exhibition parameters like yield voltage,efficiency.Athe same time the proposed topology offers the immoderate yield voltage assessment and the current-day one.

\section{APPROACH}

\subsection{Single data double yield $d c$-dc converter with four} switches:

The fig. 1 demonstrates the single statistics double yield dc-dc converter with 4 switches as proposed in [4].It carries of a dc records deliver, 4 power switches, blocking off diodes, three channel capacitors for project up and mission down yields and uninvolved segments.

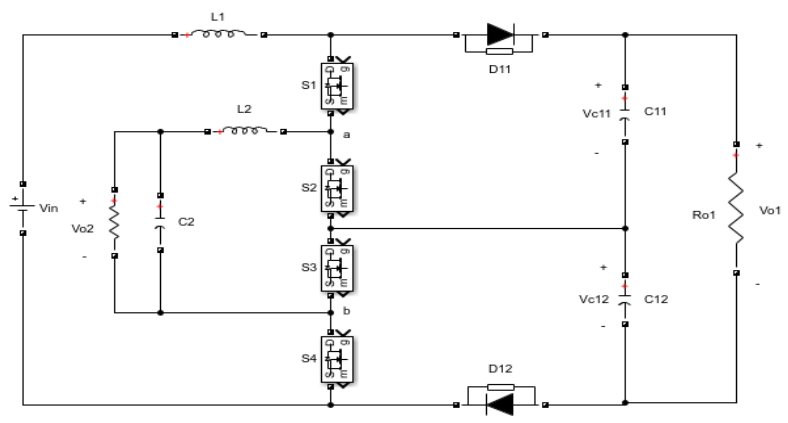

Figure 1: Single input dual output DC-DC converter with four switches

Two switches are given the obligation cycle more noteworthy than the half and the two switches are given the obligation cycle lesser than the half to get venture up and venture down yields separately. It comprises of sixteen exchanging states since increasingly number of exchanging states can't deliver same yield voltages, yet additionally not having the equivalent charging states. Thus they have comparable proportionate circuits which are indistinguishable.

\subsection{Proposed Topology}

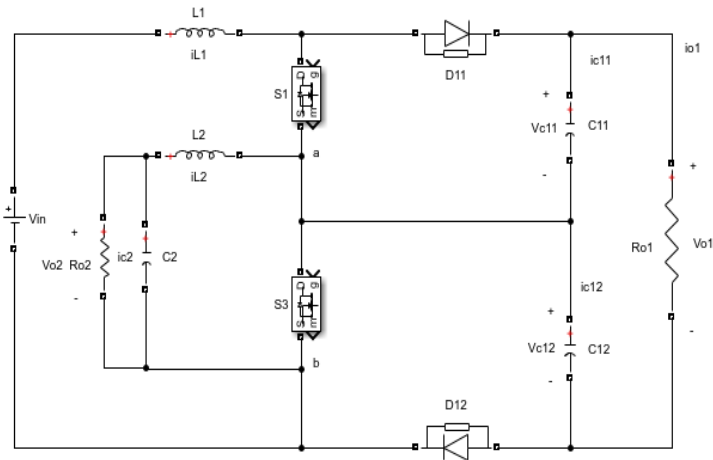

Figure 2: Modified Single input dual output DC-DC converter with two switches

Fig. 2 demonstrates the proposed topology. It comprises of info voltage Vin.Two inductors L1 and L2; two resistors Ro1 and R02; channel capacitors C11 and C12 of lift yield which are associated in arrangement; the channel capacitor $\mathrm{C} 2$ of buck output.S1 and S2 are the two power switches.D11 and D12 are the power diodes.

\subsection{Switching Pattern and Operation:}

The exchanging states are appeared in table 1 . There are four exchanging states as appeared in the table1.Vab is the unfiltered step-down voltage.VL1, VL2 are the immediate voltages of inductors.ic11 and ic12 are the flows of arrangement capacitors. At the point when the two switches are ON Volis showed up crosswise over Vab, Vin-Vo1 is showed up crosswise over VL1, Vo1-Vo2 is showed up crosswise over $\mathrm{VL} 2, \mathrm{i}_{\mathrm{L} 1}-\mathrm{l}_{\mathrm{L} 2}-\mathrm{V}_{\mathrm{o} 1} / \mathrm{R}_{\mathrm{o} 1}$ is appeared across $\mathrm{i}_{\mathrm{C} 11}$, $i_{L 1}-i_{L 2}-V_{o 1} / R_{o 1}$ is appeared across $i_{c 12}$. When one of the switch is on, $\mathrm{V}_{\mathrm{o} 1} / 2, \mathrm{~V}_{\mathrm{in}}-\mathrm{V}_{\mathrm{o} 1} / 2, \mathrm{~V}_{\mathrm{o} 1} / 2-\mathrm{V}_{\mathrm{o} 2}$ voltages are occurred at two states i.e.; 2 and 3 but $\mathrm{i}_{\mathrm{L} 1}-\mathrm{i}_{\mathrm{L} 2}-\mathrm{V}_{\mathrm{o} 1} / \mathrm{R}_{\mathrm{o} 1},-\mathrm{V}_{\mathrm{o} 1} / \mathrm{R}_{\mathrm{o} 1}$ at $\mathrm{i}_{\mathrm{c} 11}$ and $\mathrm{V}_{\mathrm{o} 1} / \mathrm{R}_{\mathrm{o} 1}, \mathrm{i}_{\mathrm{L} 1}-\mathrm{i}_{\mathrm{L} 2}-\mathrm{V}_{\mathrm{o} 1} / \mathrm{R}_{\mathrm{o} 1}$ at $\mathrm{ic}_{12}$. When the two switches are on , the zero voltage is at $\mathrm{v}_{\mathrm{ab}}, \mathrm{vi}_{\mathrm{n}}$ is at $\mathrm{V}_{\mathrm{L} 1},-\mathrm{V}_{\mathrm{o} 1} / \mathrm{R}_{\mathrm{o} 1}$ is at both $\mathrm{i}_{\mathrm{c} 11}$ and $i_{\mathrm{c} 12}$.

Table: 1 Switching States of the proposed circuit

\begin{tabular}{|c|c|c|c|c|c|c|c|}
\hline $\begin{array}{l}\text { switching } \\
\text { state }\end{array}$ & S1 & S2 & $v_{a b}$ & $v_{l 1}$ & $v_{l 2}$ & $i_{C 11}$ & $i_{C 12}$ \\
\hline 1 & 0 & 0 & $v_{o l}$ & $v_{i n}-v_{o 1}$ & $v_{o 1}-v_{o 2}$ & $\begin{array}{l}i_{L 1}-l_{L 2^{-}} \\
v_{o 1} / R_{o 1}\end{array}$ & $\begin{array}{l}i_{L 1}-i_{L 2^{-}} \\
v_{o 1} / R_{o 1}\end{array}$ \\
\hline 2 & 0 & 1 & $v_{o 1} / 2$ & $\begin{array}{l}v_{i n^{-}} \\
v_{o 1} / 2\end{array}$ & $\begin{array}{l}v_{o 1} / 2- \\
v_{o 2}\end{array}$ & $\begin{array}{l}i_{L 1}-i_{L 2^{-}} \\
v_{o 1} / R_{o 1}\end{array}$ & $-v_{o l} / R_{o l}$ \\
\hline 3 & 1 & 0 & $v_{o 1} / 2$ & $\begin{array}{l}v_{i n^{-}} \\
v_{o 1} / 2\end{array}$ & $\begin{array}{l}v_{o 1} / 2- \\
v_{02}\end{array}$ & $-v_{o l} / R_{o l}$ & $\begin{array}{l}i_{L 1}-i_{L 2^{-}} \\
v_{o 1} / R_{o 1}\end{array}$ \\
\hline 4 & 1 & 1 & 0 & $v_{\text {in }}$ & $-v_{o 2}$ & $-v_{o 1} / R_{o l}$ & $-v_{o 1} / R_{o l}$ \\
\hline
\end{tabular}




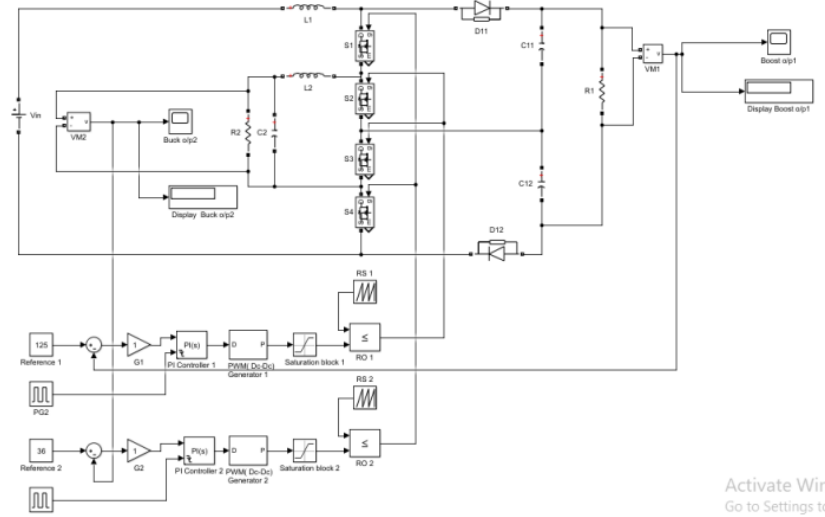

Figure 3: Simulink diagram of Existing topology

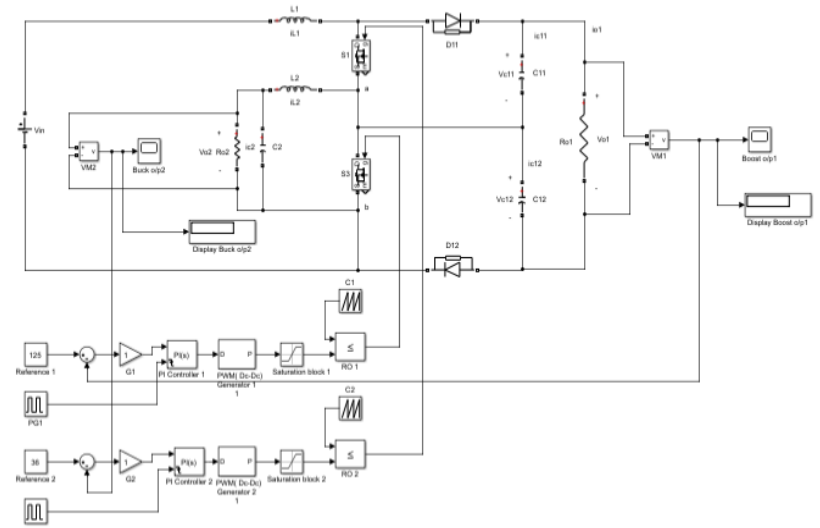

Figure 4: Simulation Diagram of Proposed Circuit

\section{RESULTS DISCUSSION}

This part discusses the results obtained from the Mat lab. These results consider four cases:

Case1:Four switch topology without controller Case2:Two switch topology without controller case3:Four switch topology with PI controller Case 1: Four switch topology without controller

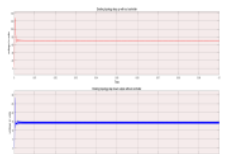

Figure 4: Graph for four switch topology without controller

Fig 4: shows the graph for four switch topology without controller.For an input of $60 \mathrm{~V}$, stepup voltage of $71.22 \mathrm{~V}$

Table 2 shows the input and output of four switch topology without controller. Case4:Two switch topology with PI controller and step down voltage of $14.85 \mathrm{~V}$ are obtained.

\begin{tabular}{|l|l|l|}
\hline \multicolumn{3}{|l|}{ Four switch topology without controller } \\
\hline S.No & INPUT & OUTPUT \\
\hline 1. & $60 \mathrm{~V}$ & $\begin{array}{l}71.22 \mathrm{~V} \\
\text { (step up) }\end{array}$ \\
\hline 2. & $60 \mathrm{~V}$ & $\begin{array}{l}14.58 \mathrm{~V} \\
\text { (step down) }\end{array}$ \\
\hline
\end{tabular}

Table2: Input and output of four switch topology without controller

Case 2: Two switch topology without controller

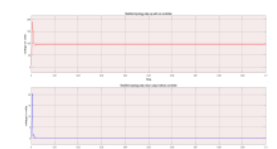

Figure 5: Graph for two switch topology without controller

Fig 5: shows the graph for two switch topology without controller.

For an input of $60 \mathrm{~V}$, stepup voltage of $94.53 \mathrm{~V}$ and step down voltage of $0.1915 \mathrm{~V}$ are obtained.

Table 3 shows the input and output of two switch topology without controller.

Table2: Input and output of four switch topology without controller

\begin{tabular}{|l|l|l|}
\hline \multicolumn{3}{|l|}{ Two switch topology without controller } \\
\hline S.NO & INPUT & OUTPUT \\
\hline 1. & $60 \mathrm{~V}$ & $\begin{array}{l}94.53 \mathrm{~V} \\
\text { (step up) }\end{array}$ \\
\hline 2. & $60 \mathrm{~V}$ & $\begin{array}{l}0.1915 \mathrm{~V} \\
\text { (step down) }\end{array}$ \\
\hline
\end{tabular}

Case 3: Four switch topology with PI controller

Published By: 
Table4: Input and output of two switch topology with PI controller

\section{COMPARISON OF RESULTS}

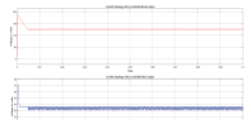

Figure 6: Graph for two switch topology without controller

Fig 6: shows the graph for four switch topology with PI controller. For an input of 60V, step-up voltage of $124.8 \mathrm{~V}$ and step down voltage of $35.99 \mathrm{~V}$ are obtained.

Table 4 shows the input and output of four switch topology with PI controller.

Table4: Input and output of four switch topology with PI controller

\section{Four switch topology with PI controller}

\begin{tabular}{|l|l|l|}
\hline S.NO & INPUT & OUTPUT \\
\hline 1. & $60 \mathrm{~V}$ & $\begin{array}{l}124.8 \mathrm{~V} \\
\text { (step up) }\end{array}$ \\
\hline 2. & $60 \mathrm{~V}$ & $\begin{array}{l}35.99 \mathrm{~V} \\
\text { (step down) }\end{array}$ \\
\hline
\end{tabular}

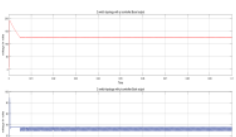

Figure 7: Two switch topology with PI controller

Fig 7: shows the graph for two switch topology with PI controller. For an input of $60 \mathrm{~V}$, step-up voltage of $125.6 \mathrm{~V}$ and step down voltage of $35.97 \mathrm{~V}$ are obtained.

Table 5 shows the input and output of two switch topology with PI controller

Two switch topology with PI controller

\begin{tabular}{|l|l|l|}
\hline S.NO & INPUT & OUTPUT \\
\hline 1. & $60 \mathrm{~V}$ & $\begin{array}{l}125.6 \mathrm{~V} \\
\text { (step up) }\end{array}$ \\
\hline 2. & $60 \mathrm{~V}$ & $\begin{array}{l}35.97 \\
\text { (step down) }\end{array}$ \\
\hline
\end{tabular}

\begin{tabular}{|c|c|c|c|}
\hline \multicolumn{4}{|c|}{ For an input of $60 \mathrm{~V}$} \\
\hline \multicolumn{2}{|c|}{ Existing Topology } & \multicolumn{2}{|c|}{ Proposed Topology } \\
\hline With out PI & With PI & With out PI & With PI \\
\hline Output & Output & Output & Output \\
\hline $\begin{array}{l}72.12 \mathrm{~V} \\
\text { step up }\end{array}$ & $\begin{array}{l}\text { 124.8V } \\
\text { Step up }\end{array}$ & $\begin{array}{l}94.53 \mathrm{~V} \\
\text { step up }\end{array}$ & $\begin{array}{l}125.6 \mathrm{~V} \\
\text { Step up }\end{array}$ \\
\hline $\begin{array}{l}14.58 \\
\text { Step down }\end{array}$ & $\begin{array}{l}\text { 35.99V } \\
\text { step down }\end{array}$ & $\begin{array}{l}0.1915 \mathrm{~V} \\
\text { step down }\end{array}$ & $\begin{array}{l}35.97 \mathrm{~V} \\
\text { step down }\end{array}$ \\
\hline
\end{tabular}

The above desk demonstrates the examination of aftereffects of each cutting-edge and proposed frameworks. inside the contemporary framework without PI controller the improvement up yield of seventy two.12V and the development down yield of 14.fifty 8 are gotten however within the proposed framework the progression up yield of $904.53 \mathrm{~V}$ and the development down yield of zero.1915V are obtained. currently with PI controlling method, in the modern framework the improvement up yield of $124.8 \mathrm{~V}$ and the development down yield of $35.99 \mathrm{~V}$ are gotten but the proposed framework the development up yield of a hundred twenty five.6V and the progression down yield of $35.97 \mathrm{~V}$ are received. it is seen from the table that the improved yields are gotten with decreased switches.

\section{CONCLUSION}

This paper proposed an adjusted topology with least extensive variety of switches. The modern-day framework implemented a four modifications activates the all the greater converting misfortunes in which because the altered framework utilized simply switches which ends up in development of voltage, decrease of changing misfortunes and the swells have been given dwindled especially. The adjusted circuit consists of of just switches which lessens the fee of circuit because of its smallness. therefore the correlation a number of the frameworks unmistakably uncovers the improvement of effectiveness and yield voltage of proposed topology of unmarried statistics double yield $\mathrm{dc}-\mathrm{dc}$ converter. The yield voltages are ninety four.53V and a hundred twenty 5.6V (with PI).

\section{REFERENCES}

1. clerici, A., Tironi, E., and Castelli-Dezza, F. (2018). Multiport converters and ESS on 3-kV DC railroad traces: Case take a look at for braking power reserve finances. IEEE Transactions onenterprise applications, fifty four(3), 2740-2750.

2. Wu, H., Zhu, L., and Yang, F. (2018). 3-Port-Converterprimarily based unmarried-segment Bidirectional AC-DC Converter with decreased electricity Processing levels and 


\section{A SINGLE INPUT DUAL OUTPUT MULTIPORT DC-DC CONVERTER WITH MINIMAL SWITCHES}

progressed normal performance. IEEE Transactions on electricity Electronics, 33(12), 10021-10026.

3. Bhattacharjee, A. k., Kutkut, N., and Batarseh, I. (2019). Survey of Multiport Converters for solar and energy storage Integration. IEEE Transactions on electricity Electronics, 34(2), 1431-1445.

4. Ganjavi, A., Ghoreishy, H., and Ahmad, A. A. (2018). a unique single-enter twin-Output 3-degree DC-DC Converter. IEEE Transactions on industrial Electronics, 65(10), 81018111.

5. Kung, S. H., and Kish, G. J. (2019). Multiport Modular Multilevel Converter for DC structures. IEEE Transactions on strength transport, 34(1), 73-eight.

6. Irfan, M. S., Ahmed, An., and Park, J. H. (2018). energydecoupling of a multiport constrained converter for an electrolytic-capacitor less staggered inverter. IEEE Transactions on electricity Electronics, 33(8), 6656-6671

7. Alsolami, M., Potty, adequate. An., and Wang, J. (2017). A gallium-nitride-device based totally totally exchanged capacitor multiport staggered converter for united states of americaapplications. IEEE Transactions on energy Electronics, 32(9), 6853-6862.

8. Karanayil, B., Ciobotaru, M., and Agelidis, V. G. (2017). strength flow the board of detached multiport converter forincreasingly electric powered powered aircraft. IEEE Transactions on power Electronics, 32(7), 5850-5861

9. Gan, C., Jin, N., solar, Q., Kong, W., Hu, Y., and Tolbert, L. M. (2018). Multiport bidirectional SRM drives for daylight hours primarily based helped $1 / 2$ and half of electric powered delivery strength educate with adaptable using and selfcharging capacities. IEEE Transactions on energy Electronics, 33(10), 8231-8245.

10. Corti, M., Tironi, E., and Ubezio, G. (2016). DC systems inclusive of multiport DC/DC converters: Fault research. IEEE Transactions on enterprise packages, 52(5), 3655-3662.

11. Yi, F., and Cai, W. (2016). A semi Z-source coordinated multiport manage converter as exchanged hesitance engine drives for capacitance lower and huge-tempo-amplifyhobby. IEEE Transactions on electricity Electronics, 31(11), 76617676.

12. Yi, F., and Cai, W. (2016). displaying, manipulate, and regular improvement of the bidirectional battery-driven exchanged hesitance engine/generator strength depending on included multiport manage converter for electric powered vehicle packages. IEEE Transactions on power Electronics, 31(10), 7099-7111.

13. Cai, W., and Yi, F. (2016). A coordinated multiport control converter with little capacitance necessity for exchanged hesitance engine stress. IEEE exchanges on power gadgets, 31(four), 3016-3026

14. Mihai, M. (2015, June). Multiport converters-a concise survey. In 2015 seventh worldwide conference on Electronics, pc structures and artificial Intelligence (ECAI) (pp. P-27) IEEE.

15. Asa, E., Colak, okay.,Bojarski, M., and Czarkowski, D. (2015). Deviated obligation cycle and degree skip manage of a unique multiport CLL thunderous converter. IEEE magazine of emerging and selected subjects in energy Electronics, 3(four), 1122-1131.

16. Itoh, ok.,Ishigaki, M., Yanagizawa, N., Tomura, S., and Umeno, T. (2015). exam and plan of a multiport converter using an attractive coupling inductor technique. IEEE Transactions on industry packages, fifty one(2), 1713-1721.

17. Wu, H., Zhang, J., and Xing, Y. (2015). a hard and fast of multiport dollar-help converters dependent on DC-connect inductors (DLIs). IEEE Transactions on power gadgets, 30(2), 735-746.

18. Hawke, J. T., Krishnamoorthy, H. S., and Enjeti, P. N. (2014). a set of new multiport manage sharing converter topologies for huge matrix associated electricity additives. IEEE mag of emerging and decided on subjects in power Electronics, 2(4), 962-971.

19. Venmathi, M., and Ramaprabha, R. (2013). a whole overview on multi-port bidirectional DC-DC Converters for sustainable power supply frameworks. ARPN J EngApplSci, eight(5), 348-fifty six. 